\title{
Tautonia plasticadhaerens sp. nov., a novel species in the family Isosphaeraceae isolated from an alga in a hydrothermal area of the Eolian Archipelago
}

\author{
Christian Jogler • Sandra Wiegand · Christian Boedeker • Anja Heuer • \\ Stijn H. Peeters • Mareike Jogler • Mike S. M. Jetten • Manfred Rohde • \\ Nicolai Kallscheuer
}

Received: 3 March 2020/ Accepted: 27 April 2020/Published online: 12 May 2020

(C) The Author(s) 2020

\begin{abstract}
A novel planctomycetal strain, designated $\mathrm{ElP}^{\mathrm{T}}$, was isolated from an alga in the shallow hydrothermal vent system close to Panarea Island in the Tyrrhenian Sea. Cells of strain ElP $^{\mathrm{T}}$ are spherical, form pink colonies and display typical planctomycetal characteristics including division by budding and presence of crateriform structures. Strain $\mathrm{ElP}^{\mathrm{T}}$ has a mesophilic (optimum at $30{ }^{\circ} \mathrm{C}$ ) and neutrophilic (optimum at $\mathrm{pH}$ 7.5) growth profile, is aerobic and heterotrophic. It reaches a generation time of $29 \mathrm{~h}$ $\left(\mu_{\max }=0.024 \mathrm{~h}^{-1}\right)$. The strain has a genome size of $9.40 \mathrm{Mb}$ with a $\mathrm{G}+\mathrm{C}$ content of $71.1 \%$ and harbours
\end{abstract}

C. Jogler $(\bowtie) \cdot$ S. H. Peeters · M. S. M. Jetten ·

N. Kallscheuer

Department of Microbiology, Radboud University,

Nijmegen, The Netherlands

e-mail: christian@jogler.de

C. Jogler · M. Jogler

Department of Microbial Interactions, Institute of

Microbiology, Friedrich Schiller University, Jena,

Germany

S. Wiegand

Institute for Biological Interfaces 5, Karlsruhe Institute of

Technology, Eggenstein-Leopoldshafen, Germany

C. Boedeker · A. Heuer

Leibniz Institute DSMZ, Brunswick, Germany

M. Rohde

Central Facility for Microscopy, Helmholtz Centre for

Infection Research, Brunswick, Germany five plasmids, the highest number observed in the phylum Planctomycetes thus far. Phylogenetically, the strain represents a novel species of the recently described genus Tautonia in the family Isosphaeraceae. A characteristic feature of the strain is its tendency to attach strongly to a range of plastic surfaces. We thus propose the name Tautonia plasticadhaerens sp. nov. for the novel species, represented by the type strain $\mathrm{ElP}^{\mathrm{T}}$ (DSM $101012^{\mathrm{T}}=\mathrm{LMG}$ $29141^{\mathrm{T}}$ ).

Keywords Marine bacteria $\cdot$ Panarea $\cdot$ Biotic surfaces · Planctomycetes - Isosphaeraceae . Hydrothermal vent system

\section{Introduction}

The phylum Planctomycetes, along with Chlamydiae, Verrucomicrobia and others, forms the PVC superphylum, which is of environmental, medical and biotechnological importance (Spring et al. 2016; Wagner and Horn 2006). Members of the phylum Planctomycetes occur in a broad range of habitats on Earth, with the largest number of species so far isolated from aquatic environments (Wiegand et al. 2018). Phylogenetically, the phylum is subdivided into the classes Phycisphaerae, Planctomycetia and Candidatus Brocadiae. Recent rearrangements in the class Planctomycetia led to a more strictly defined order 
Planctomycetales and the introduction of the orders Pirellulales, Gemmatales and Isosphaerales (Dedysh et al. 2019). Species of the class Planctomycetia divide by budding, whereas members of the class Phycipshaerae divide by binary fission. Genome size ranges of 3-12 $\mathrm{Mb}$ and a $\mathrm{G}+\mathrm{C}$ content of $40-71 \%$ have been observed in characterised strains of the phylum Planctomycetes (Ravin et al. 2018; Wiegand et al. 2020).

Strains clustering within Planctomycetia, the class with the currently highest number of characterised species in the phylum, have been shown to attach to various marine biotic surfaces, e.g. macroscopic phototrophs (Boersma et al. 2019; Bondoso et al. 2014, 2017; Peeters et al. 2020; Vollmers et al. 2017), on which they can be highly abundant (Bengtsson and Øvreås 2010). Such surfaces are suggested to serve as nutrient source, e.g. in the form of complex polysaccharides (Jeske et al. 2013; Lachnit et al. 2013). However, the survival of planctomycetal species appears counter-intuitive given their rather slow growth compared to natural competitors in this ecological niche (Frank et al. 2014; Wiegand et al. 2018). Strategies applied to compensate for lower growth rates may include the ability to produce bioactive secondary metabolites (Kallscheuer et al. 2019c; Panter et al. 2019), resistance against several antibiotics (Cayrou et al. 2010; Godinho et al. 2019) and/or a metabolism well-adapted to digestion of algae-derived compounds, including the above-mentioned polysaccharides. In this context, pili originating from conspicuous crateriform structures and an extremely enlarged periplasmic space observed in Planctomycetes may be involved in the uptake and intracellular cleavage of polymeric carbon sources, as shown for the model substrate dextran (Boedeker et al. 2017).

The cell envelope architecture of species of the phylum Planctomycetes was investigated based on super-resolution microscopic techniques and developed genetic tools (Jogler et al. 2011; Jogler and Jogler 2013; Rivas-Marin et al. 2016), which confirmed presence of peptidoglycan (Jeske et al. 2015; van Teeseling et al. 2015) and a cell envelope similar to that of Gramnegative bacteria (Boedeker et al. 2017; Devos 2014). However, in contrast to canonical bacteria, Planctomycetes lack otherwise essential divisome proteins, including FtsZ (Jogler et al. 2012; Pilhofer et al. 2008). In their genomes, $40-55 \%$ of the automatically annotated genes are of unknown function (Wiegand et al. 2020), which is a strong motivation to study the planctomycetal cell biology in greater detail.

To extend the collection of axenic cultures of Planctomycetes and as a basis for further study of their cell biology and metabolism, here we describe a novel strain, ElP ${ }^{\mathrm{T}}$, isolated from an alga sampled in the Tyrrhenian Sea close to the island Panarea.

\section{Materials and methods}

Isolation of the novel strain and cultivation

For the isolation and cultivation of strain $\mathrm{ElP}^{\mathrm{T}}, \mathrm{M} 1 \mathrm{H}$ NAG ASW medium was used. Liquid and solid M1H NAG ASW medium was prepared as previously described (Boersma et al. 2019). Strain ElP $^{\mathrm{T}}$ was isolated from an alga gathered from hydrothermal area A26 (location: $38.6392 \mathrm{~N} 15.1051 \mathrm{E}$ ). With an average depth of $26 \mathrm{~m}, \mathrm{~A} 26$ is the deepest spot of a plateau located between the small islands Le Guglie and Lisca Bianca around $2.5 \mathrm{~km}$ east of the island Panarea, Italy. The geology of area A26 in the shallow-marine hydrothermal system close to Panarea is described elsewhere (Kürzinger 2019). Algal pieces were sampled on the 10th of September 2013 at a depth of $25 \mathrm{~m}$ and a water temperature of $19.4{ }^{\circ} \mathrm{C}$. The sampled material was initially washed with sterile seawater containing $20 \mathrm{mg} / \mathrm{L}$ cycloheximide to prevent fungal growth. Afterwards, washed algal pieces were swabbed over a plate with M1H NAG ASW medium containing $8 \mathrm{~g} / \mathrm{L}$ gellan gum, $1000 \mathrm{mg} / \mathrm{L}$ streptomycin, $200 \mathrm{mg} / \mathrm{L}$ ampicillin and $20 \mathrm{mg} / \mathrm{L}$ cycloheximide, which was subsequently incubated at $20^{\circ} \mathrm{C}$ for four weeks. The 16S rRNA gene of the strains obtained was amplified by PCR with the primers $8 \mathrm{f}$ (5'-AGA GTT TGA TCM TGG CTC AG-3') and 1492r ( $5^{\prime}$-GGY TAC CTT GTT ACG ACT T- $\left.3^{\prime}\right)$ and then sequenced following a previously published protocol (Rast et al. 2017). This step was performed in order to check whether isolated strains represent members of the phylum Planctomycetes.

Determination of $\mathrm{pH}$ and temperature optimum

The $\mathrm{pH}$ optimum and range were determined in $\mathrm{M} 1 \mathrm{H}$ NAG ASW medium at $28{ }^{\circ} \mathrm{C}$. The following buffers (each $100 \mathrm{mM})$ were used: 2- $(N-$ 
morpholino)ethanesulfonic acid (MES) for $\mathrm{pH} 5.0$ and 6.0, 4-(2-hydroxyethyl)-1-piperazineethanesulfonic acid (HEPES) for $\mathrm{pH} 7.0,7.5$ and 8.0, 3-(4-(2hydroxyethyl)piperazin-1-yl)propane-1-sulfonic acid) (HEPPS) for $\mathrm{pH} \quad 8.5$ and $N$-cyclohexyl-2aminoethanesulfonic acid (CHES) for $\mathrm{pH} 9.0$ and 10.0. The temperature optimum and range were determined in standard M1H NAG ASW medium at $\mathrm{pH}$ 7.5. Growth was assessed by measuring the optical density at $600 \mathrm{~nm}\left(\mathrm{OD}_{600}\right)$. The average of $\mathrm{OD}_{600}$ values from three biological replicates was used for calculation of the growth rates. To this end, the natural logarithm of average $\mathrm{OD}_{600}$ values $\left(\ln \left(\mathrm{OD}_{600}\right)\right.$ ) was plotted against the cultivation time. The slope of the linear range of the curve (at least five data points) was used as maximal growth rate $\mu\left(\right.$ in $\left.^{-1}\right)$. The generation time $t_{d}$ (in $h$ ) was calculated using the equation $\mathrm{t}_{\mathrm{d}}=\ln (2) / \mu$.

\section{Microscopy protocols}

Phase contrast and field emission scanning electron microscopy were performed as previously described (Boersma et al. 2019).

Genome information and analysis of genome-

encoded features

Genome and plasmid sequences of strain $\operatorname{ElP}^{\mathrm{T}}$ are available from GenBank under accession numbers CP036426-CP036431. The 16S rRNA gene sequence of strain $\mathrm{ElP}^{\mathrm{T}}$ can be found under accession number MK559970. DNA isolation and genome sequencing was carried out as part of a previous study (Wiegand et al. 2020). Numbers of carbohydrate-active enzymes were obtained from the CAZY database (Lombard et al. 2014). Gene clusters potentially involved in the production of secondary metabolites were determined using antiSMASH 4.0 (Blin et al. 2017).

\section{Phylogenetic analysis}

16S rRNA gene sequence-based phylogeny was computed for strain $\mathrm{ElP}^{\mathrm{T}}$, the type strains of all described planctomycetal species (assessed in January 2020) and all isolates published in the recent year (Boersma et al. 2019; Kallscheuer et al. 2019a, b, d; Kohn et al. 2019; Kovaleva et al. 2019; Peeters et al. 2020; Rensink et al. 2020) as previously described
(Kallscheuer et al. 2019d). Three 16S rRNA genes of bacterial strains from the PVC superphylum, but outside of the phylum Planctomycetes (accession numbers AJ229235, NR_146840 and NR_027571), were used as the outgroup. The multi-locus sequence analysis (MLSA) was performed according to a previously published protocol (Kallscheuer et al. 2019d). The genomes of Gemmata obscuriglobus (accession number CP042911), Rhodopirellula baltica (accession number BX119912.1) and Gimesia maris (accession number CP043931) served as outgroup. The average nucleotide identity (ANI) was calculated using OrthoANI (Lee et al. 2016). The average amino acid identity (AAI) was obtained using the aai.rb script of the enveomics collection (Rodriguez-R and Konstantinidis 2016), while the percentage of conserved proteins (POCP) was calculated as described by Qin et al. (2014). The rpoB nucleotide sequences were taken from publicly available planctomycetal genome annotations and the sequence identities for the described $1200 \mathrm{bp}$ sequence fragment were determined as previously described (Bondoso et al. 2013). Alignment and matrix calculation were performed with Clustal Omega (Sievers et al. 2011).

\section{Results and discussion}

Phylogenetic analysis

In both, the 16S rRNA gene sequence- and the MLSAbased phylogenetic tree (Fig. 1), strain ElP $^{\mathrm{T}}$ clusters monophyletically with Tautonia sociabilis GM2012 ${ }^{\mathrm{T}}$ (Kovaleva et al. 2019). The two strains share a $16 \mathrm{~S}$ rRNA gene sequence similarity of $96.5 \%$ (Fig. 2), which is above the recommended genus threshold of $94.5 \%$, but below the species threshold of $98.7 \%$ (Stackebrandt and Ebers 2006; Yarza et al. 2014). Comparison at the 16S rRNA gene level thus suggests that strain $\mathrm{ElP}^{\mathrm{T}}$ represents a novel species in the genus Tautonia, family Isosphaeraceae. This finding is in line with an ANI of $79.8 \%$ obtained during comparison of strain $\mathrm{ElP}^{\mathrm{T}}$ and $T$. sociabilis, since this value is below the threshold of $95 \%$ for strains belonging to the same species (Kim et al. 2014). For a more extensive evaluation, additional phylogenetic markers were taken into account. Indeed, affiliation of strain ElP $^{T}$ to the genus Tautonia and simultaneous delineation 


\section{(A) 16S rRNA gene}

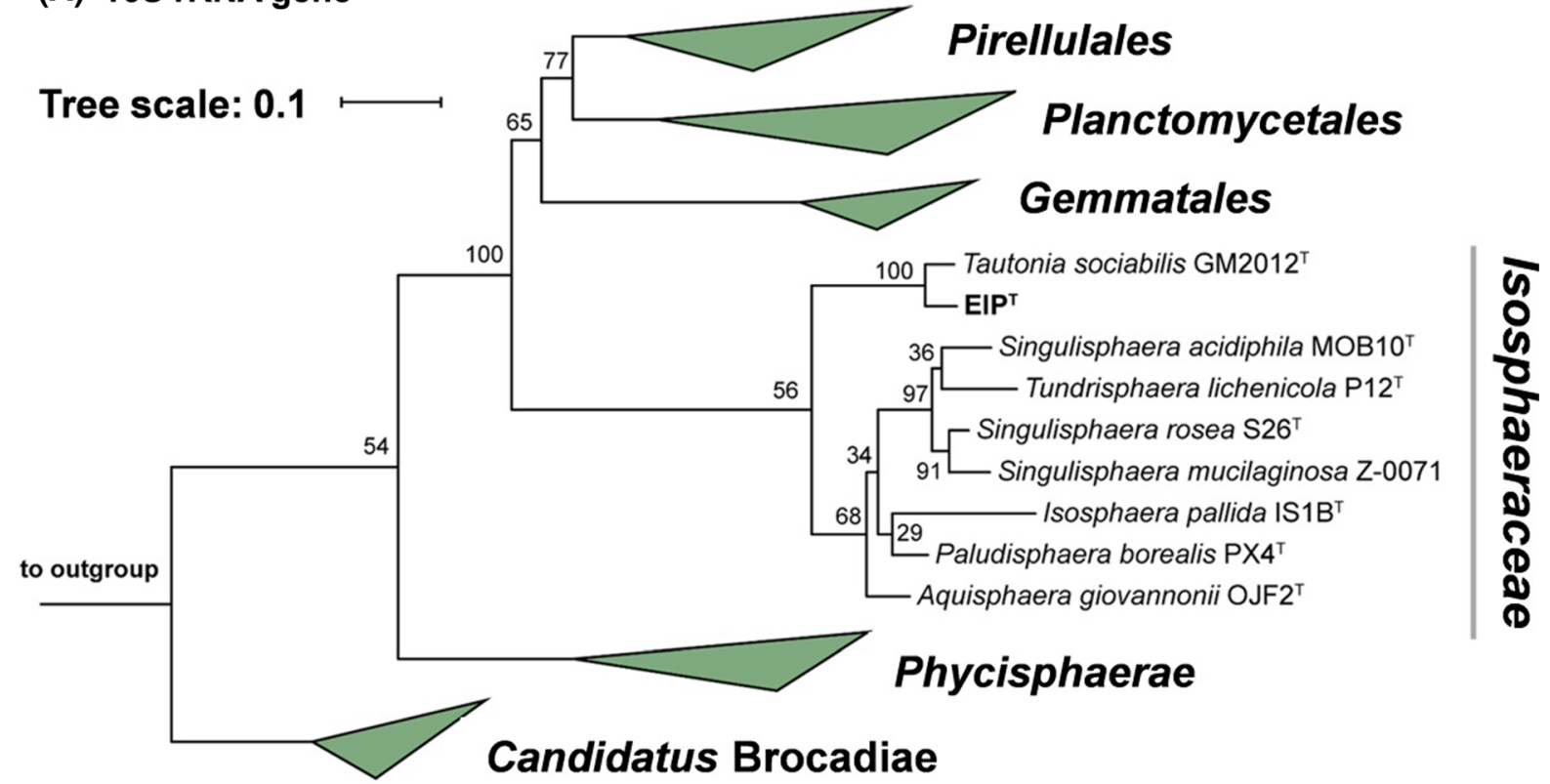

(B) MLSA

Tree scale: 0.1

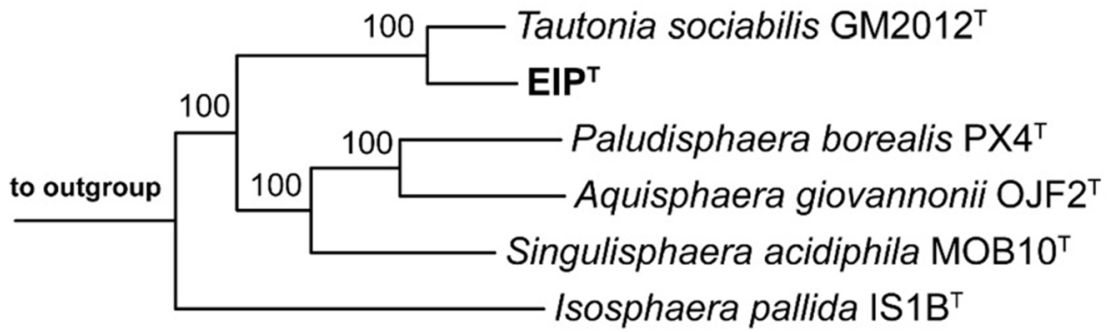

Fig. 1 Maximum likelihood phylogenetic analysis. Phylogenetic trees showing the position of strain $\mathrm{ElP}^{\mathrm{T}}$. 16S rRNA gene sequence-(a) and MLSA-based (b) phylogeny was computed as described in the "Materials and methods" section. Bootstrap values after 1000 re-samplings (16S rRNA gene sequences) and

from T. sociabilis is supported by AAI, $r p o B$ similarity and POCP values of $76.3 \%, 90.5 \%$ and $65.7 \%$, respectively (Fig. 2). These values fall above the recommended genus thresholds of $60-80 \%$ (AAI), $75.5-78 \%(r p o B)$ and $50 \%$ (POCP) for delineation of prokaryotic genera, but below the thresholds of $95 \%$ (AAI) and $96.3 \%$ (rpoB) for differentiation of species (Kallscheuer et al. 2019d; Konstantinidis and Tiedje 2005; Qin et al. 2014). T. sociabilis was clearly established as the current closest relative of strain $\mathrm{ElP}^{\mathrm{T}}$ since lower similarity values were
500 re-samplings (MLSA) are given at the nodes (in \%). The outgroups consist of three $16 \mathrm{~S}$ rRNA genes from the PVC superphylum (16S rRNA-based tree) or the genome sequences of Gemmata obscuriglobus, Rhodopirellula baltica and Gimesia maris (MLSA-based tree)

obtained for comparison with species of other known genera in the family Isosphaeraceae, namely Isosphaera, Singulisphaera, Aquisphaera, Paludisphaera and Tundrisphaera. For comparison of strain $\mathrm{ElP}^{\mathrm{T}}$ with species of the mentioned genera, AAI and $16 \mathrm{~S}$ rRNA gene similarity values are below the genus threshold, while in most cases the POCP was found to be at or slightly above the genus threshold of $50 \%$ (Fig. 2). Similarity of rpoB is used as phylogenetic marker in the order Planctomycetales (Bondoso et al. 2013) and a genus threshold of $75.5-78 \%$ was 


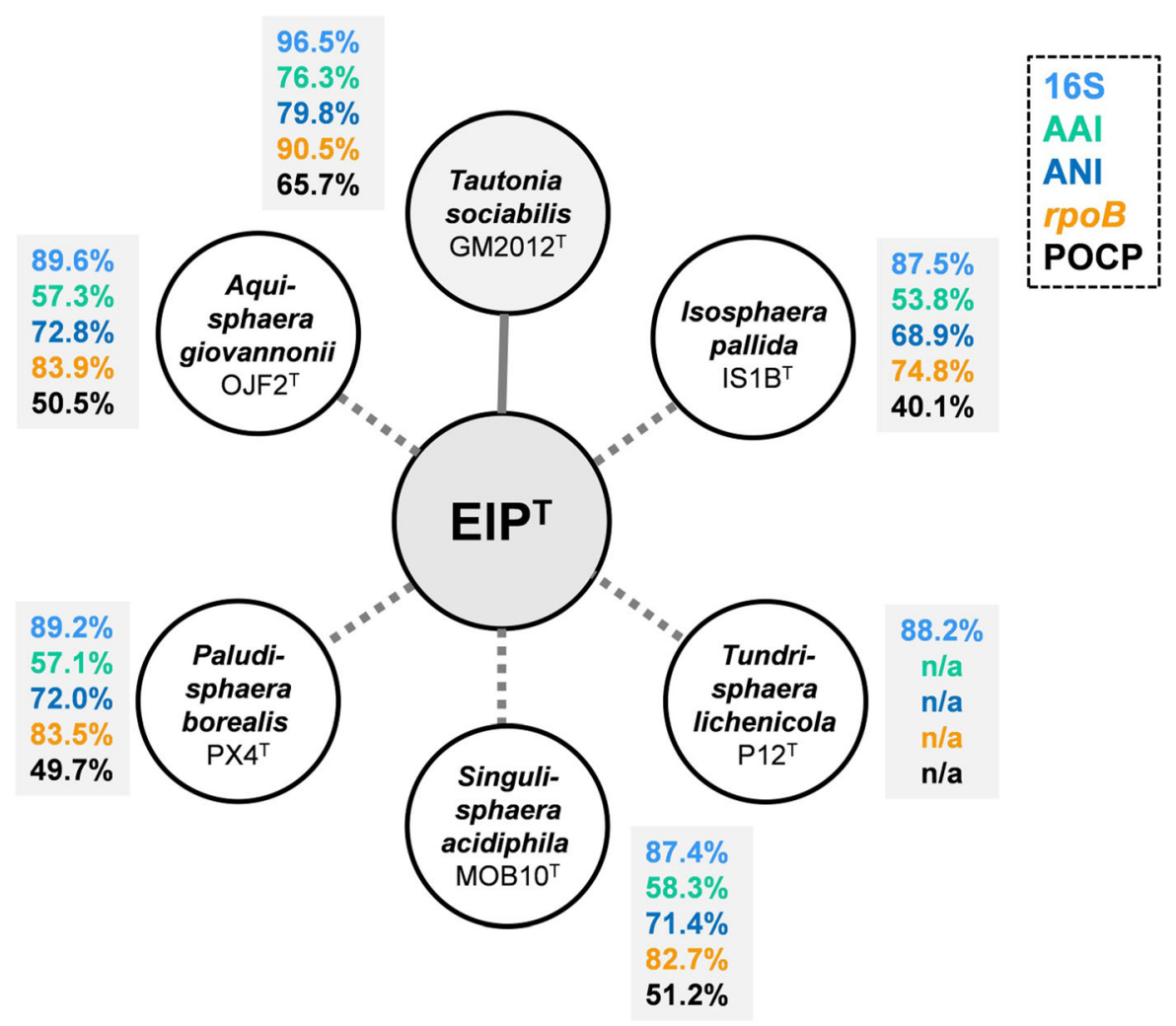

Fig. 2 Similarity values of strain $\mathrm{ElP}^{\mathrm{T}}$ in relation to species in the family Isosphaeraceae. Methods used: 16S rRNA gene sequence identity (16S), average amino acid identity (AAI),

recently proposed based on new strains in the family Pirellulaceae (former members of Planctomycetaceae) (Kallscheuer et al. 2019d). Based on the obtained values (Fig. 2), the rpoB genus threshold is probably not applicable to the family Isosphaeraceae.

Morphological and physiological analyses

Basic features of strain $\mathrm{ElP}^{\mathrm{T}}$ comprising cell morphology, growth and mechanism of cell division are summarised in Table 1 and compared to T. sociabilis, Isosphaera pallida, Tundrisphaera lichenicola, Singulisphaera acidiphila, Paludisphaera borealis and Aquisphaera giovannonii (Bondoso et al. 2011; Giovannoni et al. 1987; Kovaleva et al. 2019; Kulichevskaya et al. 2008, 2016, 2017). Morphological features of $\mathrm{ElP}^{\mathrm{T}}$ cells harvested during the exponential growth phase were analysed using phase contrast and scanning electron microscopy (Fig. 3). Strain $\mathrm{ElP}^{\mathrm{T}}$ forms spherical cells with a typical diameter of 1.4-2.0 $\mu \mathrm{m}$ (Fig. 3a, c), which occur either as single cells or form average nucleotide identity (ANI), rpoB gene identity (1200 bp fragment) and percentage of conserved proteins (POCP)

smaller aggregates of 25-40 cells. Cells divide by budding with the bud having the same shape as the mother cell (Fig. 3a). Cell size and shape of $\mathrm{ElP}^{\mathrm{T}}$ are comparable to the type species of known genera in the family Isosphaeraceae, with the exception of $I$. pallida, which forms cells that are considerably larger. All seven compared strains follow the same mode of division and contain crateriform structures on the entire cell surface (no data available for T. sociabilis). The colonies of $\mathrm{ElP}^{\mathrm{T}}$ have a pink pigmentation, suggesting the production of carotenoids. The colour is similar to the species chosen for comparison, with the exception of S. acidiphila and the closely related $T$. sociabilis, which lack pigmentation (Table 1). Once isolated, colonies of strain $\mathrm{ElP}^{\mathrm{T}}$ were observed to grow at the plastic boundary of the Petri dish, only half connected to the agar surface. This tendency to stick to plastic surfaces necessitated the use of glassware for handling of the strain. For example, cells stuck strongly to plastic pipettes, making their transfer difficult. This immediate adsorption towards plastic 
Table 1 Phenotypic and genotypic features of strain $\mathrm{ElP}^{\mathrm{T}}$ compared to closely related strains. The genome analysis is based on GenBank accession numbers for strain $\mathrm{ElP}^{\mathrm{T}}$ (CP036426-CP036431), Tautonia sociabilis (GCA_003977685.1), Isosphaera pallida (CP002353-
CP002354), Singulisphaera acidiphila (CP003364CP003367), Paludisphaera borealis (CP019082-CP019084) and Aquisphaera giovannonii (CP042997-CP042999). The genome of Tundrisphaera lichenicola has not been sequenced yet

\begin{tabular}{|c|c|c|c|c|c|c|c|}
\hline Feature & $\mathrm{ElP}^{\mathrm{T}}$ & $\begin{array}{l}\text { Tautonia } \\
\text { sociabilis } \\
\text { GM2012 }^{\mathrm{T}}\end{array}$ & $\begin{array}{l}\text { Isosphaera } \\
\text { pallida } \\
\mathrm{IS}_{1 \mathrm{~B}} \mathrm{~B}^{\mathrm{T}}\end{array}$ & $\begin{array}{l}\text { Tundrisphaera } \\
\text { lichenicola } \\
\mathrm{P} 12^{\mathrm{T}}\end{array}$ & $\begin{array}{l}\text { Singulisphaera } \\
\text { acidiphila } \\
\mathrm{MOB}_{10}^{\mathrm{T}}\end{array}$ & $\begin{array}{l}\text { Paludisphaera } \\
\text { borealis } \\
\mathrm{PX} 4^{\mathrm{T}}\end{array}$ & $\begin{array}{l}\text { Aquisphaera } \\
\text { giovannonii } \\
\text { OJF2 }^{\mathrm{T}}\end{array}$ \\
\hline \multicolumn{8}{|c|}{ Phenotypic characteristics } \\
\hline Shape & Spherical & Spherical & Spherical & Spherical & Spherical & Spherical & Spherical \\
\hline Diameter $(\mu \mathrm{m})$ & $1.7 \pm 0.3$ & $1.7-2.9$ & $2.5-3.0$ & $2.2-3.0$ & $1.6-2.6$ & $1.5-2.5$ & $1.6-2.0$ \\
\hline Colour & Pink & White & Pink & Pink & White & Bright pink & Pink \\
\hline Relation to oxygen & Aerobic & $\begin{array}{l}\text { Strictly } \\
\text { aerobic }\end{array}$ & $\begin{array}{l}\text { Strictly } \\
\text { aerobic }\end{array}$ & Strictly aerobic & Strictly aerobic & Aerobic & $\begin{array}{l}\text { Strictly } \\
\text { aerobic }\end{array}$ \\
\hline $\begin{array}{l}\text { Temperature range } \\
\text { (optimum) }\left({ }^{\circ} \mathrm{C}\right)\end{array}$ & $10-33(30)$ & $\begin{array}{r}37-46 \\
(42)\end{array}$ & $34-55(41)$ & $4-28(15-22)$ & $4-33(20-26)$ & $6-30(15-25)$ & $10-35(30)$ \\
\hline $\begin{array}{l}\mathrm{pH} \text { range } \\
\text { (optimum) }\end{array}$ & $\begin{array}{c}6-0-8.5 \\
(7.5)\end{array}$ & $\begin{array}{l}5.5-9.0 \\
(7.5)\end{array}$ & $7.8-8.8$ & $\begin{array}{l}4.5-6.8 \\
\quad(5.5-6.0)\end{array}$ & $\begin{array}{l}4.2-7.5 \\
\quad(5.0-6.2)\end{array}$ & $\begin{array}{l}3.5-6.5(5.0 .- \\
5.5)\end{array}$ & $\begin{array}{l}6.5-9.5 \\
\quad(7.5-8.5)\end{array}$ \\
\hline Division & Budding & Budding & Budding & Budding & Budding & Budding & Budding \\
\hline $\begin{array}{l}\text { Dimorphic life } \\
\text { cycle }\end{array}$ & n.o. & n.d. & n.d. & n.d. & n.d. & n.d. & n.d. \\
\hline Motility & No & No & $\begin{array}{l}\text { Yes, } \\
\text { phototactic } \\
\text { gliding }\end{array}$ & No & No & No & No \\
\hline $\begin{array}{c}\text { Crateriform } \\
\text { structures }\end{array}$ & Ubiquitous & n.d. & Ubiquitous & Ubiquitous & Ubiquitous & Ubiquitous & Ubiquitous \\
\hline Fimbriae & Yes & n.d. & Yes & n.d. & n.d. & n.d. & Yes \\
\hline Capsule & Yes & n.d. & No & n.d. & Yes & n.d. & Yes \\
\hline Stalk & n.o. & n.d. & n.d. & No & No & n.d. & n.d. \\
\hline Holdfast structure & n.o. & n.d. & No & Yes & Yes & Yes & n.d. \\
\hline \multicolumn{8}{|c|}{ Genomic characteristics } \\
\hline Genome size (bp) & $9,395,224$ & $6,760,005$ & $5,529,304$ & n.d. & $9,755,686$ & $7,651,896$ & $10,526,296$ \\
\hline Plasmids & 5 & n.d. & 1 & n.d. & 3 & 2 & 2 \\
\hline $\mathrm{G}+\mathrm{C}(\%)$ & $71.1 \pm 0.8$ & 70.1 & $62.5 \pm 3.2$ & $61.2-62.2$ & $62.2 \pm 2.3$ & $66.3 \pm 4.1$ & $70.8 \pm 0.5$ \\
\hline Coding density $(\%)$ & 84.7 & 85.0 & 84.7 & n.d. & 83.5 & 86.1 & 85.7 \\
\hline Completeness (\%) & 98.28 & 98.28 & 98.28 & n.d. & 98.28 & 96.55 & 96.55 \\
\hline Contamination (\%) & 5.17 & 3.45 & 0 & n.d. & 6.90 & 3.45 & 5.17 \\
\hline Total genes & 7707 & 5183 & 3828 & n.d. & 7689 & 5961 & 7953 \\
\hline Genes/Mb & 820 & 767 & 692 & n.d. & 788 & 779 & 756 \\
\hline Giant genes & 0 & 0 & 0 & n.d. & 1 & 0 & 1 \\
\hline $\begin{array}{l}\text { All protein-coding } \\
\text { genes }\end{array}$ & 7556 & 5084 & 3761 & n.d. & 7540 & 5855 & 7835 \\
\hline $\begin{array}{l}\text { Protein-coding } \\
\text { genes/Mb }\end{array}$ & 804 & 752 & 680 & n.d. & 773 & 765 & 744 \\
\hline $\begin{array}{l}\text { Hypothetical } \\
\text { proteins }\end{array}$ & 3399 & 3175 & 1821 & n.d. & 4316 & 3154 & 3328 \\
\hline tRNAs & 100 & 84 & 51 & n.d. & 81 & 83 & 107 \\
\hline 16S rRNA genes & 3 & 1 & 3 & n.d. & 8 & 3 & 3 \\
\hline
\end{tabular}

n.o. not observed, n.d. not determined 

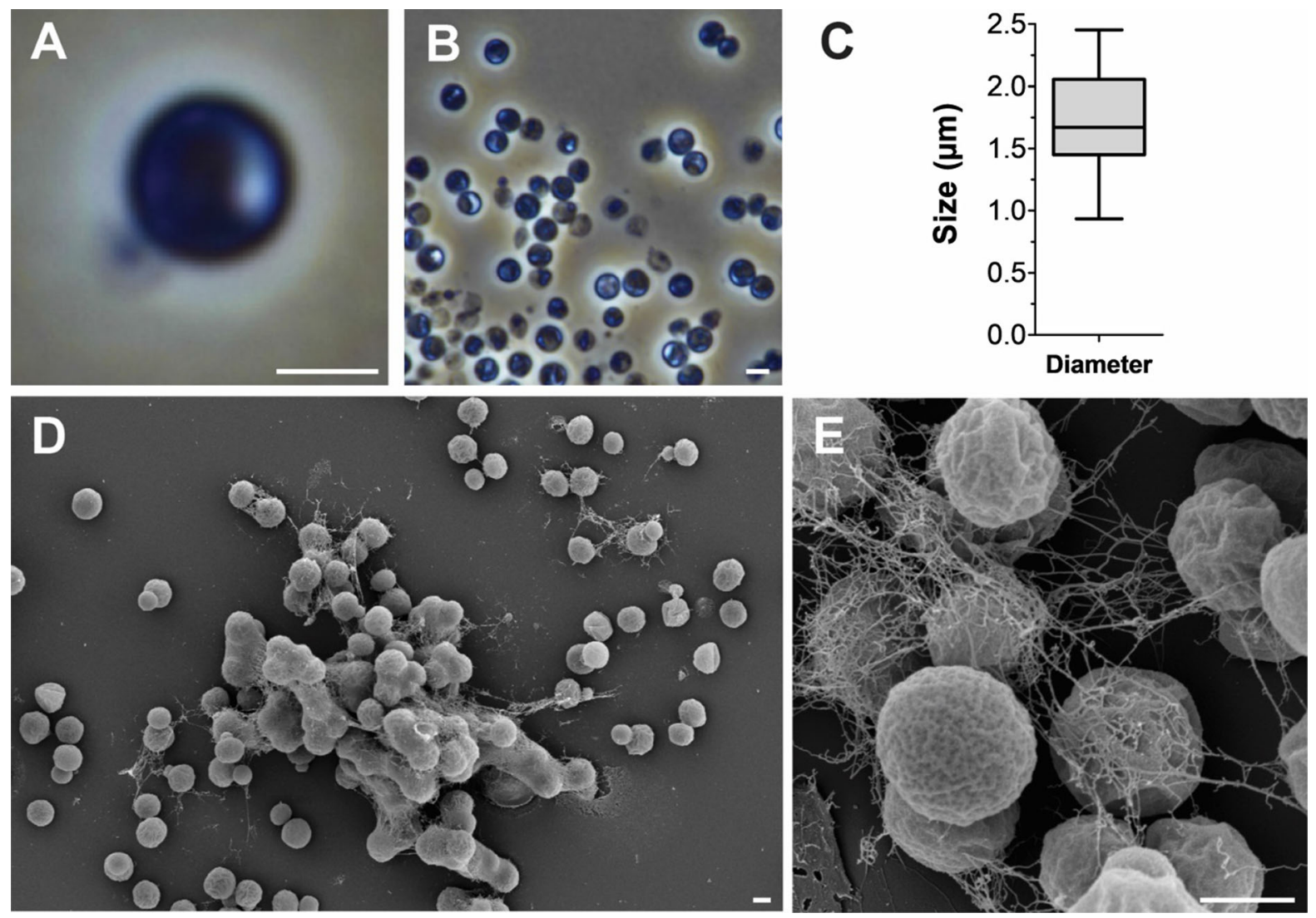

Fig. 3 Microscopy images and cell size plot of strain $\mathrm{ElP}^{\mathrm{T}}$. The mode of cell division (a) and a general overview of the cell morphology (b, d, e) is shown. Cells tend to form aggregates surrounded by an extracellular matrix $(\mathbf{d}+\mathbf{e})$. The scale bar is

surfaces might be related to the extracellular matrix abundantly produced by strain $\operatorname{ElP}^{\mathrm{T}}$ (Fig. 3e). The strain was determined to be non-motile as are the other reference species, except I. pallida, which displays phototactic gliding motility (Giovannoni et al. 1987).

In M1H NAG ASW medium, strain ElP $^{\mathrm{T}}$ was able to grow over a temperature range of $10-33{ }^{\circ} \mathrm{C}$ and a $\mathrm{pH}$ range of 6.0-8.5 (Fig. 4). Strain $\mathrm{ElP}^{\mathrm{T}}$ was found to be aerobic, heterotrophic, mesophilic and neutrophilic. Optimal growth was observed at $30{ }^{\circ} \mathrm{C}$ and $\mathrm{pH} 7.5$, which led to a maximal growth rate of $0.024 \mathrm{~h}^{-1}$, corresponding to a generation time of $29 \mathrm{~h}$ (Fig. 4). The family Isosphaeraceae appears to be heterogeneous regarding temperature and $\mathrm{pH}$ preferences. S. acidiphila, T. lichenicola and P. borealis favour lower temperatures $\left(15-26^{\circ} \mathrm{C}\right)$ compared to strain $\mathrm{ElP}^{\mathrm{T}}\left(30^{\circ} \mathrm{C}\right)$, whereas I. pallida and T. sociabilis are thermophiles with optimal growth at
$1 \mu \mathrm{m}$. For determination of the cell size (c) at least 100 representative cells were counted manually or by using a semiautomated object count tool

$41-42{ }^{\circ} \mathrm{C}$ and a temperature range allowing growth up to $55^{\circ} \mathrm{C}$ (Table 1 ). With regard to $\mathrm{pH}$, I. pallida and A. giovannonii are adapted to slightly alkaline growth conditions ( $\mathrm{pH} 8-9$ ), whereas $S$. acidiphila, T. lichenicola and $P$. borealis require more acidic environments (pH 5-6). Strain ElP $^{\mathrm{T}}$ and T. sociabilis grow optimally under neutral conditions ( $\mathrm{pH} 7-7.5)$. These differences likely reflect the different natural habitats from which the strains were isolated. I. pallida was isolated from a hot spring, explaining the preference for higher temperatures, while e.g. S. acidiphila was isolated from a Sphagnum peat moss, which are typically found in nutrient-poor and acidic peat bogs (Giovannoni et al. 1987; Kulichevskaya et al. 2008). 


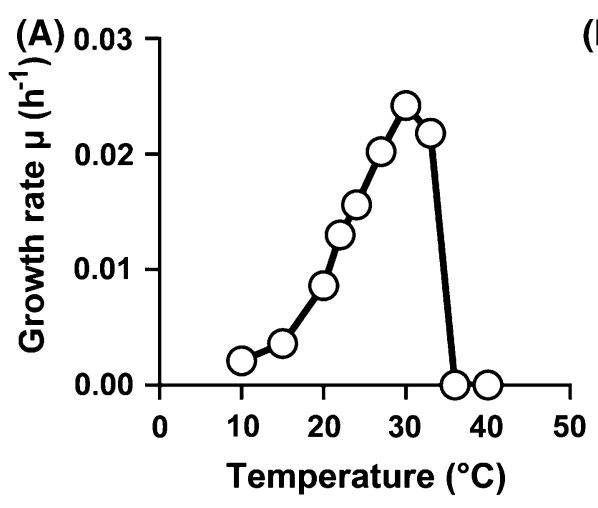

Fig. 4 Temperature and $\mathrm{pH}$ optimum of $\mathrm{ElP}^{\mathrm{T}}$. The graphs show the average growth rates obtained from cultivation of the strain in M1H NAG ASW medium in biological triplicates.

Genomic characteristics

The complete genome of strain $\mathrm{ElP}^{\mathrm{T}}$ has a size of $9.40 \mathrm{Mb}$, distributed among the chromosome $(8.67 \mathrm{Mb})$ and five plasmids (with sizes of 0.28 , $0.14,0.12,0.09$ and $0.09 \mathrm{Mb}$ ). While plasmids are scarce among Planctomycetes, the family Isosphaeraceae is exceptional in that regard (Ivanova et al. 2017). Five strains of this family harbour at least one plasmid (no data available for T. sociabilis), while four plasmids was the current maximum observed in strain SH-PL62 (Ivanova et al. 2017). Strain ElP ${ }^{\mathrm{T}}$ maintains five extrachromosomal replicons in parallel, making it a potential resource for future planctomycetal genetic tool development.

The $\mathrm{G}+\mathrm{C}$ content of strain $\mathrm{ElP}^{\mathrm{T}}$ is $71.1 \%$. In its genome, 7707 genes were annotated, of which 7556 are putative protein-coding genes. The number of hypothetical proteins is 3399 , corresponding to $45 \%$ of the total number of putatively annotated proteins. The number of protein-coding genes yields 804 encoded proteins per $\mathrm{Mb}$ and a coding density of $84.7 \% .100$ tRNAs and three copies of the 16S rRNA gene were identified. The genomic characteristics of the compared strains are quite heterogeneous (Table 1). With $5.53 \mathrm{Mb} \mathrm{I}$. pallida has by far the smallest genome, while the genomes of strain $\mathrm{ElP}^{\mathrm{T}}, S$. acidiphila and $A$. giovannonii fall in a size range of 9.4-10.6 Mb. Their $\mathrm{G}+\mathrm{C}$ content varies from 62 to $71 \%$, with strain $\mathrm{ElP}^{\mathrm{T}}$ showing the highest $\mathrm{G}+\mathrm{C}$ content of the compared strains. One giant gene $(>5 \mathrm{~kb})$ was found in $S$. acidiphila and $A$. giovannonii, while the other three strains lack giant genes. The genome of T. lichenicola
(B) 0.020

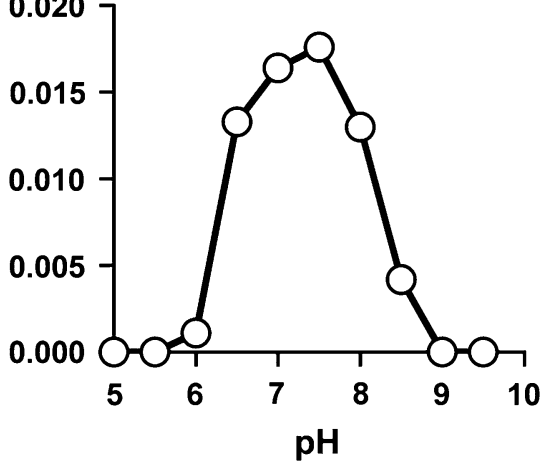

Cultivations at different temperatures (a) were performed at $\mathrm{pH} 7.5$ and cultivations at different $\mathrm{pH}$ values (b) were conducted at $28^{\circ} \mathrm{C}$

has not been sequenced yet and could thus not be used for comparison.

Genome-based analysis of the primary and secondary metabolism

The genome sequences of species belonging to the family Isosphaeraceae provide important information on their metabolic capabilities. The suggested capability of Planctomycetes to degrade high molecular weight sugars is likely reflected by high numbers of carbohydrate-active enzymes encoded in their genomes, while production of secondary metabolites is often related to interactions with the abiotic and biotic environment, including response to external stress factors. The compared members of the family Isosphaeraceae harbour between 109 and 317 carbohydrate-active enzymes and a clear correlation between the number of enzymes and the genome size was observed (Table 2). Only S. acidiphila slightly deviates from this trend. It has the second largest genome of the compared species, but is only ranked 3rd with regard to the number of carbohydrate-active enzymes. Strain $\mathrm{ElP}^{\mathrm{T}}$ has a 5\% smaller genome, but its number of carbohydrate-active enzymes is around $10 \%$ higher. Analysis of the distribution to the different enzyme families shows that glycoside hydrolases and glycosyl transferases account for $80-90 \%$ of the total number in all five strains. A. giovannonii has a considerably higher number of enzymes of the glycoside hydrolase family, which is 2.5 times as high as in strain $\mathrm{ElP}^{\mathrm{T}}$ (second highest number of enzymes of this family) and almost seven times as high 
Table 2 Numbers of carbohydrate-active enzymes and secondary metabolite-associated gene clusters in $\mathrm{ElP}^{\mathrm{T}}$ in comparison to other species in the family Isosphaeraceae. The analysis is based on GenBank accession numbers for strain $\mathrm{ElP}^{\mathrm{T}} \quad$ (CP036426-CP036431), Tautonia sociabilis

\begin{tabular}{|c|c|c|c|c|c|c|}
\hline Feature & $\mathrm{ElP}^{\mathrm{T}}$ & $\begin{array}{l}\text { Tautonia } \\
\text { sociabilis } \\
\mathrm{GM}^{\mathrm{G}} 2012^{\mathrm{T}}\end{array}$ & $\begin{array}{l}\text { Isosphaera } \\
\text { pallida } \\
\mathrm{IS}^{\mathrm{S}} \mathrm{B}^{\mathrm{T}}\end{array}$ & $\begin{array}{l}\text { Singulisphaera } \\
\text { acidiphila } \\
\mathrm{MOB}^{\mathrm{T}}{ }^{\mathrm{T}}\end{array}$ & $\begin{array}{l}\text { Paludisphaera } \\
\text { borealis } \\
\mathrm{PX}^{\mathrm{T}}\end{array}$ & $\begin{array}{l}\text { Aquisphaera } \\
\text { giovannonii } \\
\mathrm{OJF}^{\mathrm{T}}\end{array}$ \\
\hline Genome size $(\mathrm{Mb})$ & 9.40 & 6.76 & 5.53 & 9.76 & 7.65 & 10.53 \\
\hline \multicolumn{7}{|l|}{ Carbohydrate-active enzymes } \\
\hline Glycoside Hydrolase Family & 59 & n.d. & 21 & 49 & 52 & 142 \\
\hline Glycosyl Transferase Family & 123 & n.d. & 74 & 117 & 86 & 120 \\
\hline $\begin{array}{l}\text { Polysaccharide Lyase } \\
\text { Family }\end{array}$ & 3 & n.d. & 2 & 1 & 0 & 3 \\
\hline $\begin{array}{l}\text { Carbohydrate Esterase } \\
\text { Family }\end{array}$ & 13 & n.d. & 5 & 9 & 9 & 17 \\
\hline $\begin{array}{l}\text { Carbohydrate-Binding } \\
\text { Module Family }\end{array}$ & 16 & n.d. & 7 & 14 & 21 & 35 \\
\hline Total number & 214 & n.d. & 109 & 190 & 168 & 317 \\
\hline \multicolumn{7}{|c|}{ Secondary metabolite-associated clusters } \\
\hline Terpenoid & 3 & 2 & 3 & 3 & 2 & 2 \\
\hline Type I Polyketide synthase & 1 & 1 & 1 & 2 & 3 & 2 \\
\hline Type II Polyketide synthase & 0 & 0 & 0 & 0 & 0 & 0 \\
\hline Type III Polyketide synthase & 0 & 0 & 1 & 0 & 1 & 1 \\
\hline $\begin{array}{l}\text { Non-ribosomal peptide } \\
\text { synthetase }\end{array}$ & 0 & 0 & 0 & 0 & 0 & 1 \\
\hline Bacteriocin & 0 & 2 & 0 & 1 & 0 & 1 \\
\hline Resorcinol & 0 & 0 & 0 & 0 & 0 & 0 \\
\hline Total number & 4 & 5 & 5 & 6 & 6 & 7 \\
\hline
\end{tabular}

(GCA_003977685.1), Isosphaera pallida (CP002353CP002354), Singulisphaera acidiphila (CP003364CP003367), Paludisphaera borealis (CP019082-CP019084) and Aquisphaera giovannonii (CP042997-CP042999) 
have escaped the in silico prediction by the AntiSMASH tool.

Taken together, comparison of morphological, physiological and genomic features in the heterogeneous family Isosphaeraceae supports the results of the phylogenetic analysis, which leads us to the conclusion that strain $\mathrm{ElP}^{\mathrm{T}}$ represents a novel species in the genus Tautonia. Thus, we propose the name Tautonia plasticadhaerens for this species, represented by the type strain $\operatorname{ElP}^{\mathrm{T}}$ (DSM $101012^{\mathrm{T}}=\mathrm{LMG}$ $29141^{\mathrm{T}}$ ).

Emended genus description of Tautonia Kovaleva et al. (2019)

The description of the genus is as previously published (Kovaleva et al. 2019), with the following modification: species of this genus are mesophilic or thermotolerant.

\section{Tautonia plasticadhaerens sp. nov.}

Plas.tic.ad.hae'rens. N.L. neut. n. plasticum plastic; L. pres. part. adhaerens adhering, sticking to; N.L. part. adj. plasticadhaerens attaching to plastic, due to the tendency of the type strain to attach strongly to plastic surfaces.

Cells are spherical (diameter $1.7 \pm 0.3 \mu \mathrm{m}$ ), occur as single cells or small aggregates and divide by budding. Stalk-free and non-motile cells, which contain crateriform structures covering the entire cell surface. Cells produce an extracellular matrix and strongly attach to plastic surfaces. Colonies are pink. Cells of the type strain grow over a temperature range of $10-33{ }^{\circ} \mathrm{C}$ (optimum $30^{\circ} \mathrm{C}$ ) and at $\mathrm{pH}$ 6.0-8.5 (optimum 7.5). The genome of the type strain has a size of $9.40 \mathrm{Mb}$, which is distributed among the chromosome and five plasmids. The $\mathrm{G}+\mathrm{C}$ content is $71.1 \%$.

The type strain is $\mathrm{ElP}^{\mathrm{T}}$ (DSM 101012 ${ }^{\mathrm{T}}=\mathrm{LMG}$ $29141^{\mathrm{T}}$ ), isolated from an alga close to Panarea Island in September 2013.

Acknowledgements Open Access funding provided by Projekt DEAL. Part of this research was funded by the Deutsche Forschungsgemeinschaft Grants KA 4967/1-1 and JO 893/4-1, Grant ALWOP.308 of the Nederlandse Organisatie voor Wetenschappelijk Onderzoek (NWO), SIAM (Soehngen Institute for Anaerobic Microbiology) Grant No. 024002002 and the Radboud Excellence fellowship. We thank Ina
Schleicher for skilful technical assistance. Brian Tindall and Regine Fähnrich from the DSMZ as well as the BCCM/LMG Bacteria collection we thank for support during strain deposition. We thank the Scientific Diving Center of the Bergakademie Freiberg, Germany, Thomas Pohl, Peter Hornburger and all participants of the 2013 Panarea Expedition for sampling support.

Author contributions NK wrote the manuscript and analysed the cultivation data, SW performed the genomic and phylogenetic analysis, $\mathrm{AH}$ and $\mathrm{MJ}$ isolated the strains and performed the initial cultivation and strain deposition, SHP and $\mathrm{CB}$ performed the light microscopic analysis and prepared the LM pictures, MSMJ contributed to text preparation and revised the manuscript, MR performed the electron microscopic analysis and prepared the SEM pictures, CJ supervised AH and the study. All authors read and approved the final version of the manuscript.

\section{Compliance with ethical standards}

Conflict of interest The authors declare that they have no conflict of interest.

Ethical approval This article does not contain any studies with animals performed by any of the authors.

Open Access This article is licensed under a Creative Commons Attribution 4.0 International License, which permits use, sharing, adaptation, distribution and reproduction in any medium or format, as long as you give appropriate credit to the original author(s) and the source, provide a link to the Creative Commons licence, and indicate if changes were made. The images or other third party material in this article are included in the article's Creative Commons licence, unless indicated otherwise in a credit line to the material. If material is not included in the article's Creative Commons licence and your intended use is not permitted by statutory regulation or exceeds the permitted use, you will need to obtain permission directly from the copyright holder. To view a copy of this licence, visit http://creativecommons.org/licenses/by/4.0/.

\section{References}

Bengtsson MM, Øvreås L (2010) Planctomycetes dominate biofilms on surfaces of the kelp Laminaria hyperborea. BMC Microbiol 10:261

Blin K, Wolf T, Chevrette MG, Lu X, Schwalen CJ, Kautsar SA, Suarez Duran HG, de Los Santos EL, Kim HU, Nave M (2017) antiSMASH 4.0-improvements in chemistry prediction and gene cluster boundary identification. Nucleic Acids Res 45:W36-W41

Boedeker C, Schuler M, Reintjes G, Jeske O, van Teeseling MC, Jogler M, Rast P, Borchert D, Devos DP, Kucklick M, Schaffer M, Kolter R, van Niftrik L, Engelmann S, Amann R, Rohde M, Engelhardt H, Jogler C (2017) Determining the bacterial cell biology of Planctomycetes. Nat Commun $8: 14853$ 
Boersma AS, Kallscheuer N, Wiegand S, Rast P, Peeters SH, Mesman RJ, Heuer A, Boedeker C, Jetten MS, Rohde M, Jogler M, Jogler C (2019) Alienimonas californiensis gen. nov. sp. nov., a novel Planctomycete isolated from the kelp forest in Monterey Bay. Antonie van Leeuwenhoek. https:// doi.org/10.1007/s10482-019-01367-4

Bondoso J, Albuquerque L, Nobre MF, Lobo-da-Cunha A, da Costa MS, Lage OM (2011) Aquisphaera giovannonii gen. nov., sp. nov., a planctomycete isolated from a freshwater aquarium. Int J Syst Evol Microbiol 61:2844-2850

Bondoso J, Harder J, Lage OM (2013) rpoB gene as a novel molecular marker to infer phylogeny in Planctomycetales. Antonie van Leeuwenhoek 104:477-488

Bondoso J, Balague V, Gasol JM, Lage OM (2014) Community composition of the Planctomycetes associated with different macroalgae. FEMS Microbiol Ecol 88:445-456

Bondoso J, Godoy-Vitorino F, Balague V, Gasol JM, Harder J, Lage OM (2017) Epiphytic Planctomycetes communities associated with three main groups of macroalgae. FEMS Microbiol Ecol 93:fiw255

Cayrou C, Raoult D, Drancourt M (2010) Broad-spectrum antibiotic resistance of Planctomycetes organisms determined by Etest. J Antimicrob Chemother 65:2119-2122

Dedysh SN, Kulichevskaya IS, Beletsky AV, Ivanova AA, Rijpstra WIC, Damsté JSS, Mardanov AV, Ravin NV (2019) Lacipirellula parvula gen. nov., sp. nov., representing a lineage of planctomycetes widespread in lowoxygen habitats, description of the family Lacipirellulaceae fam. nov. and proposal of the orders Pirellulales ord. nov., Gemmatales ord. nov. and Isosphaerales ord. nov. Syst Appl Microbiol 43:126050

Devos DP (2014) PVC bacteria: variation of, but not exception to, the Gram-negative cell plan. Trends Microbiol 22:14-20

Frank O, Michael V, Pauker O, Boedeker C, Jogler C, Rohde M, Petersen J (2014) Plasmid curing and the loss of grip - The 65-kb replicon of Phaeobacter inhibens DSM 17395 is required for biofilm formation, motility and the colonization of marine algae. Syst Appl Microbiol 38:120-127

Giovannoni S, Schabtach E, Castenholz R (1987) Isosphaera pallida, gen. and comb. nov., a gliding, budding eubacterium from hot springs. Arch Microbiol 147:276-284

Godinho O, Calisto R, Ovreas L, Quinteira S, Lage OM (2019) Antibiotic susceptibility of marine Planctomycetes. Antonie van Leeuwenhoek 112:1273-1280

Ivanova AA, Naumoff DG, Miroshnikov KK, Liesack W, Dedysh SN (2017) Comparative genomics of four Isosphaeraceae planctomycetes: a common pool of plasmids and glycoside hydrolase genes shared by Paludisphaera borealis $\mathrm{PX}^{\mathrm{T}}$, Isosphaera pallida $\mathrm{IS} 1 \mathrm{~B}^{\mathrm{T}}$, Singulisphaera acidiphila DSM $18658^{\mathrm{T}}$, and strain SHPL62. Front Microbiol 8:412

Jeske O, Jogler M, Petersen J, Sikorski J, Jogler C (2013) From genome mining to phenotypic microarrays: Planctomycetes as source for novel bioactive molecules. Antonie van Leeuwenhoek 104:551-567

Jeske O, Schüler M, Schumann P, Schneider A, Boedeker C, Jogler M, Bollschweiler D, Rohde M, Mayer C, Engelhardt H, Spring S, Jogler C (2015) Planctomycetes do possess a peptidoglycan cell wall. Nat Commun 6:7116
Jogler M, Jogler C (2013) Towards the development of genetic tools for Planctomycetes. In: Fuerst JA (ed) Planctomycetes: cell structure, origins and biology. Springer, Berlin, pp 141-164

Jogler C, Glöckner FO, Kolter R (2011) Characterization of Planctomyces limnophilus and development of genetic tools for its manipulation establish it as a model species for the phylum Planctomycetes. Appl Environ Microbiol 77:5826-5829

Jogler C, Waldmann J, Huang X, Jogler M, Glöckner FO, Mascher T, Kolter R (2012) Identification of proteins likely to be involved in morphogenesis, cell division, and signal transduction in Planctomycetes by comparative genomics. J Bacteriol 194:6419-6430

Kallscheuer N, Jogler M, Wiegand S, Peeters SH, Heuer A, Boedeker C, Jetten MS, Rohde M, Jogler C (2019a) $R u$ binisphaera italica sp. nov. isolated from a hydrothermal area in the Tyrrhenian Sea close to the volcanic island Panarea. Antonie van Leeuwenhoek. https://doi.org/10. 1007/s10482-019-01329-w

Kallscheuer N, Jogler M, Wiegand S, Peeters SH, Heuer A, Boedeker C, Jetten MS, Rohde M, Jogler C (2019b) Three novel Rubripirellula species isolated from plastic particles submerged in the Baltic Sea and the estuary of the river Warnow in northern Germany. Antonie van Leeuwenhoek. https://doi.org/10.1007/s10482-019-01368-3

Kallscheuer N, Moreira C, Airs R, Llewellyn CA, Wiegand S, Jogler C, Lage OM (2019c) Pink-and orange-pigmented Planctomycetes produce saproxanthin-type carotenoids including a rare $\mathrm{C}_{45}$ carotenoid. Environ Microbiol Rep 11:741-748

Kallscheuer N, Wiegand S, Peeters SH, Jogler M, Boedeker C, Heuer A, Rast P, Jetten MS, Rohde M, Jogler C (2019d) Description of three bacterial strains belonging to the new genus Novipirellula gen. nov., reclassificiation of Rhodopirellula rosea and Rhodopirellula caenicola and readjustment of the genus threshold of the phylogenetic marker rpoB for Planctomycetaceae. Antonie van Leeuwenhoek. https://doi.org/10.1007/s10482-019-01374-5

Kim M, Oh H-S, Park S-C, Chun J (2014) Towards a taxonomic coherence between average nucleotide identity and $16 \mathrm{~S}$ rRNA gene sequence similarity for species demarcation of prokaryotes. Int J Syst Evol Microbiol 64:346-351

Kohn T, Wiegand S, Boedeker C, Rast P, Heuer A, Schüler M, Rohde C, Müller R-W, Brümmer F, Rohde M, Engelhardt H, Jogler M, Jogler C (2019) Planctopirus ephydatiae, a novel Planctomycete isolated from a freshwater sponge. Syst Appl Microbiol 43:126022

Konstantinidis KT, Tiedje JM (2005) Towards a genome-based taxonomy for prokaryotes. J Bacteriol 187:6258-6264

Kovaleva OL, Elcheninov AG, Toshchakov SV, Novikov AA, Bonch-Osmolovskaya EA, Kublanov IV (2019) Tautonia sociabilis gen. nov., sp. nov., a novel thermotolerant planctomycete, isolated from a $4000 \mathrm{~m}$ deep subterranean habitat. Int J Syst Evol Microbiol 69:2299-2304

Kulichevskaya IS, Ivanova AO, Baulina OI, Bodelier PL, Damste JSS, Dedysh SN (2008) Singulisphaera acidiphila gen. nov., sp. nov., a non-filamentous, Isosphaera-like planctomycete from acidic northern wetlands. Int J Syst Evol Microbiol 58:1186-1193 
Kulichevskaya IS, Ivanova AA, Suzina NE, Rijpstra WIC, Damste JSS, Dedysh SN (2016) Paludisphaera borealis gen. nov., sp. nov., a hydrolytic planctomycete from northern wetlands, and proposal of Isosphaeraceae fam. nov. Int J Syst Evol Microbiol 66:837-844

Kulichevskaya IS, Ivanova AA, Detkova EN, Rijpstra WIC, Damsté JSS, Dedysh SN (2017) Tundrisphaera lichenicola gen. nov., sp. nov., a psychrotolerant representative of the family Isosphaeraceae from lichen-dominated tundra soils. Int J Syst Evol Microbiol 67:3583-3589

Kürzinger V (2019) Determination and differentiation of the hydrothermal precipitates of Panarea, Italy, FOG-Freiberg Online Geoscience, Nr. 54

Lachnit T, Fischer M, Kunzel S, Baines JF, Harder T (2013) Compounds associated with algal surfaces mediate epiphytic colonization of the marine macroalga Fucus vesiculosus. FEMS Microbiol Ecol 84:411-420

Lee I, Ouk Kim Y, Park SC, Chun J (2016) OrthoANI: An improved algorithm and software for calculating average nucleotide identity. Int $J$ Syst Evol Microbiol 66:1100-1103

Lombard V, Golaconda Ramulu H, Drula E, Coutinho PM, Henrissat B (2014) The carbohydrate-active enzymes database (CAZy) in 2013. Nucleic Acids Res 42:D490D495

Panter F, Garcia R, Thewes A, Zaburannyi N, Bunk B, Overmann J, Gutierrez MV, Krug D, Müller R (2019) Production of a dibrominated aromatic secondary metabolite by a Planctomycete implies complex interaction with a macroalgal host. ACS Chem Biol 14:2713-2719

Peeters SH, Wiegand S, Kallscheuer N, Jogler M, Heuer A, Jetten MS, Rast P, Boedeker C, Rohde M, Jogler C (2020) Three marine strains constitute the novel genus and species Crateriforma conspicua in the phylum Planctomycetes. Antonie van Leeuwenhoek. https://doi.org/10.1007/ s10482-019-01375-4

Pilhofer M, Rappl K, Eckl C, Bauer AP, Ludwig W, Schleifer KH, Petroni G (2008) Characterization and evolution of cell division and cell wall synthesis genes in the bacterial phyla Verrucomicrobia, Lentisphaerae, Chlamydiae, and Planctomycetes and phylogenetic comparison with rRNA genes. J Bacteriol 190:3192-3202

Qin Q-L, Xie B-B, Zhang X-Y, Chen X-L, Zhou B-C, Zhou J, Oren A, Zhang Y-Z (2014) A proposed genus boundary for the prokaryotes based on genomic insights. J Bacteriol 196:2210-2215

Rast P, Glockner I, Boedeker C, Jeske O, Wiegand S, Reinhardt R, Schumann P, Rohde M, Spring S, Glockner FO, Jogler C, Jogler M (2017) Three novel species with peptidoglycan cell walls form the new genus Lacunisphaera gen. nov. in the family Opitutaceae of the Verrucomicrobial subdivision 4. Front Microbiol 8:202

Ravin NV, Rakitin AL, Ivanova AA, Beletsky AV, Kulichevskaya IS, Mardanov AV, Dedysh SN (2018) Genome analysis of Fimbriiglobus ruber $\mathrm{SP}^{\mathrm{T}}$, a planctomycete with confirmed chitinolytic capability. Appl Environ Microbiol 84:e02645-e2717

Rensink S, Wiegand S, Kallscheuer N, Rast P, Peeters SH, Heuer A, Boedeker C, Jetten MS, Rohde M, Jogler M,
Jogler C (2020) Description of the novel planctomycetal genus Bremerella, containing Bremerella volcania sp. nov., isolated from an active volcanic site, and reclassification of Blastopirellula cremea as Bremerella cremea comb. nov. Antonie van Leeuwenhoek. https://doi.org/10. 1007/s10482-019-01378-1

Rivas-Marin E, Canosa I, Santero E, Devos DP (2016) Development of genetic tools for the manipulation of the Planctomycetes. Front Microbiol 7:914

Rodriguez-R LM, Konstantinidis KT (2016) The enveomics collection: a toolbox for specialized analyses of microbial genomes and metagenomes. PeerJ Preprints 4:e1900v1

Sievers F, Wilm A, Dineen D, Gibson TJ, Karplus K, Li W, Lopez R, McWilliam H, Remmert M, Söding J (2011) Fast, scalable generation of high-quality protein multiple sequence alignments using Clustal Omega. Mol Syst Biol 7:539

Spring S, Bunk B, Spröer C, Schumann P, Rohde M, Tindall BJ, Klenk H-P (2016) Characterization of the first cultured representative of Verrucomicrobia subdivision 5 indicates the proposal of a novel phylum. ISME J 10:2801

Stackebrandt E, Ebers J (2006) Taxonomic parameters revisited: tarnished gold standards. Microbiol Today 33:152-155

van Teeseling MC, Mesman RJ, Kuru E, Espaillat A, Cava F, Brun YV, VanNieuwenhze MS, Kartal B, van Niftrik L (2015) Anammox Planctomycetes have a peptidoglycan cell wall. Nat Commun 6:6878

Vollmers J, Frentrup M, Rast P, Jogler C, Kaster AK (2017) Untangling genomes of novel Planctomycetal and Verrucomicrobial species from Monterey Bay Kelp Forest metagenomes by refined binning. Front Microbiol 8:472

Wagner M, Horn M (2006) The Planctomycetes, Verrucomicrobia, Chlamydiae and sister phyla comprise a superphylum with biotechnological and medical relevance. Curr Opin Biotechnol 17:241-249

Wiegand S, Jogler M, Jogler C (2018) On the maverick Planctomycetes. FEMS Microbiol Rev 42:739-760

Wiegand S, Jogler M, Boedeker C, Pinto D, Vollmers J, RivasMarín E, Kohn T, Peeters SH, Heuer A, Rast P, Oberbeckmann S, Bunk B, Jeske O, Meyerdierks A, Storesund JE, Kallscheuer N, Lücker S, Lage OM, Pohl T, Merkel BJ, Hornburger P, Müller R-W, Brümmer F, Labrenz M, Spormann AM, Op den Camp HJM, Overmann J, Amann R, Jetten MSM, Mascher T, Medema MH, Devos DP, Kaster A-K, Øvreås L, Rohde M, Galperin MY, Jogler C (2020) Cultivation and functional characterization of 79 planctomycetes uncovers their unique biology. Nat Microbiol 5:126-140

Yarza P, Yilmaz P, Pruesse E, Glöckner FO, Ludwig W, Schleifer KH, Whitman WB, Euzeby J, Amann R, RosselloMora R (2014) Uniting the classification of cultured and uncultured bacteria and archaea using 16S rRNA gene sequences. Nat Rev Microbiol 12:635-645

Publisher's Note Springer Nature remains neutral with regard to jurisdictional claims in published maps and institutional affiliations. 